\title{
Practice and Exploration of Communist Teacher as Sponsor of College Students Joining the Party
}

\author{
Dawei Ke \\ Jingdezhen Ceramic Institute, Jingdezhen, Jiangxi 333403, China
}

\begin{abstract}
Keywords: Teacher communist; College students; Sponsor for joining the party; Philosophy requirements; Socialist core values
\end{abstract}

\begin{abstract}
College students are the very important sources of talent in the future development of the party and the state, especially for the student communist or the party activists, it is the excellent group of college students. The article mainly analyzes the introduction, the leading, the model role of the teachers' communist in the process of the university students joining the party from the philosophical level, the value level and the working level, and provides the thinking for improving the quality of the student communist.
\end{abstract}

\section{Introduction}

Since the reform and opening up, all kinds of works in the process of socialist construction have made unprecedented development, and the reason why our country has achieved remarkable achievements is that the strong leadership of the party and the precise grasp of the direction of socialist construction. In the critical period of reform and development, human resources or intellectual resources gradually become an important manifestation of comprehensive national strength, and college students is the very important source of talents in the future development process for party and our country, especially that student communist or party activists are more outstanding groups in the college students. Therefore, how to guide college students to establish the correct ideological values, how to be a good sponsor for college students to join the party is extremely important thing for teachers.

"Teachers, teaching the principles, skills, and solving the doubt", said Han Yu, the Tang Dynasty politicians and writer in the opening of "Teachers Speak", but also the most concise summary for the career of teachers in ancient times and modern times. At the same time, in the process of college students actively moving closer to the party organization, how to play the roles of the introduction, lead, and model for teacher communists is directly related to the level of development of student communist of the ' members. Based on this, the article mainly from the philosophical level, the value level and the work level to analyze how to play the role of teachers in the process of joining the party for college students, to provide reflection for improving the quality of student communist.

\section{Teacher Communist as the Sponsor for College Students to Join the Party is Philosophical Requirements to Grasp the Dialectical Unity Relation}

First of all, teachers and college students (preparatory party members or party activists) both belong to the relationship of unity and opposite. Teachers and college students are opposed to the two groups, the former has the decisive right for college students to join the party. When We see the opposite of the two sides, at the same time, we also need to see the unity of the two sides, whether teacher communist or the party activists, the process of inspection or the party process is the embodiment of the party spirit, the concept in practice. The two sides have a unified ideological values and spiritual pursuit, and all serve the great cause of socialist construction. Only fully grasping the relationship between the two sides, can we do a good job of party members development. In addition, grasping the relationship between teacher communist and college students need to adhere to the principle of coming from practice and going into practice, we must make a comprehensive study from the study, life, work and other aspects, if the students do not meet the party spirit or requirements in any aspect, then the teacher communist need to educate, 
supervise and guide them in this aspect.

The primary characteristic of college students party activists is student. This feature is reflected that they are lack of comprehensive, accurate, historical knowledge in the students' basic theory of the party, the historical understanding of the party, the party's social role, the political status of the party, the future development of the party and so on, is still in the stage of learning knowledge, cultivating consciousness, still need to accept guidance and help from the sponsor. Therefore, the "teaching the principle" link is the primary task of the teacher communist as the sponsor of the university students, that is, through the rich historical reserves, the solid theoretical foundation, the forefront of the party's innovative achievements, profound practical experience to give students the most vivid, intuitive teaching and guidance process, so that students step into the theoretical teaching classroom, so that students deepen into the cause of socialist construction, to correct the motivation to join the party and correct attitude to join the party, making students fully be aware of the seriousness of the party.

\section{Teachers Communist as the Sponsor for College Students to Join the Party is the Important Embodiment to Implement the Socialist Core Values}

In addition to the requirements of the philosophical level, teachers communist as the sponsor for college students to join the party is the important embodiment to implement the socialist core values. The 18th National Congress of the Communist Party of China (CPC) stressed that "advocating prosperity, democracy, civilization, harmony, freedom, equality, justice, the rule of law, patriotism, dedication, integrity and friendliness, and actively cultivate and practice the socialist core values." therefore, The process of play the positive role of communist is the process of implementing the socialist core values, it is suitable for both teacher communist and student members. Specifically, firstly, the candidates in the party selection needs to reflect the concept of democracy, freedom, students can choose their favorite teacher communist, and teachers can also choose the right students, that is, the process is a two-way interactive process.

Second, in the links of party members help and guidance, teachers need to guide students to understand and grasp the socialist core values from a number of dimensions, so that students feel profound theoretical significance, practical significance and the significance of the times of the socialist core values. For example, professional teachers of the history can learn from the perspective of historians to introduce the Communist Party revolution and the construction of a major turning point, historical achievements and historical experience to the party activists or preparatory members, so that students understand the Communist Party how to overcome obstacles and achieve leapfrog development under the serious domestic and international environment. Taking "two bombs and one star" for example, in the face of environment of foreign blockade, the weak scientific and technological strength, it is a group of patriotic, dedicated, dedicated science and technology workers (such as Deng Jiaxian, Qian Sanqiang, Qian Ji etc.), through their unremitting efforts, and ultimately make our country become the fifth country holding atomic bombs and launching satellites.

Third, in the link of supervising and management for sponsor, teachers particularly need to practice equality, justice, friendly concept. There is no doubt that the ideological state, learning situation and working conditions for every college student who join the party are different, if in the process of joining the party, teacher communist can not be fair and just attitude to treat every student, then not only can not play a very good demonstration role, but also damage the demands and motives of individual students to join the party, not conducive to the development of student party members in an orderly manner.

\section{Teacher Communist as the Sponsor for College Students to Join the Party is the Important Guarantee to Examine the Quality of Student Members}

Finally, in terms of the direct function of the sponsor, the teacher communist as sponsor is the important guarantee for the university students to join the party or the quality of student members. 
Because college students joining the party is a very serious and rigorous process, which requires the party organizations in the process of studying college students must adhere to the strict, dynamic study of the principle. Strict requirements of the party organization must make the comprehensive and in-depth study on the ideological, learning, living, work and other aspects, accurately identify the weak point of students in the party activists, after the discovery of the problem we need to seriously implement related spirit of the document to help students to correct, such as "two learn and one do" activities and so on. Because the college students who join the party are more, the content of party organizations need to examine is also more, so only the power of the party can not do everything, and the supervision and inspection behavior of teachers is the supplement and improvement of the party organization, not only improve the accuracy of the study of college student members, but also improve the mode of study of college students to join the party.

Dynamic means that the quality of student members is not an overnight process, teachers must be required to give full play to the subjective initiative, in-depth understand the whole process of college students to join the party, the application submission, the party activists training party, Branch of the General Assembly and other processes are all included in the scope of the study, find and solve any one of the potential problems one by one. The task of the teachers is not only to examine, supervise the students, but also to reflect the problems to the party organization in a timely manner, to form systematic and normative education and rectification views, and through the systemic education and training activities to solve the outstanding problems of the students group, thus forming effective interaction between teachers and students, between party organizations and teachers, between the party organization and students.

For young teachers party members, because their ages are close to college students, and the generation gap is small, so getting along well with the students in the shortest possible time can help the party to more deeply grasp the student situation; and for middle-age school teachers, because of its rich social experience, a solid theoretical foundation, they can analyze the existing problems of the students joining party from a higher perspective, can put forward a number of constructive, targeted development proposals. It is undeniable that the professionalism, theoretical and cognitive advantages of teacher communist are more conducive to examining the real situation of students' participation in the study and understanding of the party's theory and principles and policies. In the case of professionalism, teachers can discuss the issue of joining the party with the students, discuss the problem of joining the party, help them to reverse the wrong understanding, but also can combine the professional theory to help students understand the party's principles and policies, to improve and deepen the party's understanding. At present, all colleges and universities have basically improved the class teacher work, the class teachers are the professional teachers. The class teacher can not only study the students through the teaching activities to be the party activists, but also in the process of day-to-day management of students and ideological communication process to study students to be the party activists.

\section{Conclusion}

It can be found that it is of great significance to give full play to the introduction, leading, exemplary and leading role of the teacher communist in the process of college students moving closer to the party organization. The most critical is that teachers need to understand the role of teacher members from three dimensions. In terms of the "teaching the principle" dimension, teacher members need to show the outstanding theories and outstanding achievements of the party to college students and guide students to move closer to the party organization; on the "teaching skills" dimension, the teachers need to carry out a lot of student activities for college students to in-depth understand school construction, carry out social practice so that the theory of practice go with the reality and the "Road" is rooted in society " Soil "; in terms of " solving doubts ", teachers need to understand the ideological situation and values of college students, to find out the" utilitarian problem "," attitude problem "and" motive problem "in college students' joining the party, really help Students solve the ideological confusion. There is no doubt that college students joining the party is not just the form of the party, but also the process of thinking into the party, so the 
introduction, leading, exemplary and leading role of teachers not only need to be reflected in the process of joining the party, and the need to run through the whole college students.

\section{Acknowledgments}

Fund Project: This article is the result of Jiangxi Provincial University Party Building Research Project (JXGXDJKT.QN-201525) "Problem-oriented Research on Unqualified Sponsor of Joining the Party in the Development of College Student Party Members ".

\section{References}

[1] R.H. Xu. Strengthen the organizational construction of young teachers and students in the development of party members [J]. Pu'er College, 1996 (02).

[2] W.G. Lu, A.D. Hu. To do a good job of developing communist from outstanding young teachers and students [J]. Guilin Teachers College, 2002 (01).

[3] S. Yao. Playing the positive role of teachers and do the development work of student party members well-important significance of teacher communist as the sponsor for students to be the party activists[J]. Seeking Truth, $2010(01)$.

[4] Y.Y. Li. The path exploration of ideological and political theory teachers to participate in the work of college students party members[J]. Journal of Qingyuan Vocational and Technical College, 2014 (02). 